\title{
PENGARUH PENYULUHAN TENTANG POLA MAKAN PADA PENDERITA DIABETES DENGAN DAN TANPA KOMPLIKASI DI KECAMATAN GETASAN
}

\author{
Elian Gina Hapsari ${ }^{1}$, Junet Franzisca da Costa ${ }^{2}$, Franzesca Dwi Wahyu ${ }^{3}$ \\ Prodi Ilmu Gizi Fakultas Kedokteran dan Ilmu Kesehatan \\ Universitas Kristen Satya Wacana \\ junetdacosta@staff.uksw.edu
}

\begin{abstract}
Diabetes Meliitus (DM) is an incurable disease or life-alive disease. Management of diabetes mellitus is not only dependent on health workers, patients and families also have an important role in controlling blood sugar levels.Diabetes mellitus often appear along with the incidence of uric acid and hypertension due to imbalance of normal components. The research was conducted in Getasan Subdistrict and aimed to see if there is any relationship between diabetes mellitus with the occurrence of uric acid and hypertension and to see the effect of counseling given to dietary change of DM patient. The results showed that diabetes had a significant relationship with uric acid containing $p=0.040(<0.05)$ and the counseling did not affect the diet of the research samples in which the statistical test result was 0.478 (> 0.005).
\end{abstract}

Keywords: diabetes mellitus, gout, hypertension, counseling, diet

PENDAHULUAN

Diabetes Mellitus (DM) biasa disebut dengan the silent killer karena penyakit ini dapat mengenai semua organ tubuh dan menimbulkan berbagai macam keluhan. Penyakit yang akan ditimbulkan antara lain gangguan penglihatan mata, katarak, penyakit jantung, sakit ginjal, impotensi seksual, luka sulit sembuh dan membusuk/gangren, infeksi paru-paru, gangguan pembuluh darah, stroke dan sebagainya. Tidak jarang, penderita DM yang sudah parah menjalani amputasi anggota tubuh karena terjadi pembusukan. Dari profil kesehatan Kabupaten Semarang tahun 2013 terdapat 7.672 jiwa penderita diabetes mellitus, tahun 2014 terdapat 8.843 jiwa penderita diabetes melitus dan pada tahun 2015 dapat dilihat bahwa angka penderita diabetes mellitus mencapai 12.448 jiwa. Tingginya prevalensi Diabetes Melitus disebabkan oleh faktor risiko yang tidak dapat berubah misalnya jenis kelamin, umur, dan faktor genetik. Ada beberapa jenis diabetes mellitus yaitu diabetes mellitus tipe 1, diabetes mellitus tipe 2, diabetes mellitus tipe gestasional, dan diabetes mellitus tipe lainnya. Jenis diabetes mellitus yang paling banyak diderita adalah diabetes mellitus tipe 2. diabetes mellitus tipe 2 (DM tipe 2) adalah penyakit gangguan metabolik yang di tandai oleh kenaikan gula darah akibat penurunan sekresi insulin oleh sel beta pankreas dan atau ganguan fungsi insulin (resistensi insulin) (Depkes, 2005).

Diabetes Mellitus memiliki kaitan dengan kejadian asam urat dimana kadar asam urat juga dapat ditandai dengan terjadinya hiperurisemia yang merupakan salah satu ciri-ciri pada penderita diabetes mellitus. Hiperurisemia terjadi bila kadar asam urat melebihi daya larutnya dalam plasma yaitu $6,7 \mathrm{mg} / \mathrm{dLpadasuhu} 37^{\circ} \mathrm{C}$. Kondisi ini dapat disebabkan karena ketidak seimbangan antara produksi yang berlebihan,dan penurunan ekskresi atau gabungan keduanya. Produksi yang berlebihanterjadipadakeadaan diet tinggipurin, alkoholisme, turn over nukleotida yang meningkat, obesitas, dandislipidemia. Sedangkan penurunan ekskresi asam urat terjadi pada penyakit ginjal, hipertensi, penggunaan diuretik, resistensi insulin, dan kadar estrogen yang rendah (Johnson dkk., 2003). Pokok masalah dari Diabetes Mellitus dan Asam Urat adalah gangguan pada sirkulasi darah dan resistensi insulin pada penderita Diabetes Mellitus yang memainkan peran sebagai faktor pemicu perkembangan Asam Urat. Hal ini disebabkan sirkulasi darah yang buruk memungkinkan Asam Urat muncul dimana kerja ginjal melemah dan tidak efisien ketika melepaskan purin menyebabkan tingkat keasaman pada darah meningkat dan $\mathrm{pH}$ menjadi tidak seimbang. Selain itu adapula faktor yang mempengaruhi munculnya komplikasi lain pada diabetes mellitus yaitu pola makan atau perilaku makan yang keliru. 
Perilaku makan adalah cara seseorang berfikir, berpengetahuan dan berpandangan tentang makanan. Apa yang ada dalam perasaan dan pandangan itu dinyatakan dalam bentuk tindakan makan dan memilih makanan. Jika keadaan itu terus menerus berulang maka tindakan tersebut akan menjadi kebiasaan makan (Ramayulis,2008). Kecamatan Getasan memiliki penderita diabetes mellitus yang cukup banyak yaitu 169 orang penderita diabetes (Profil Kesehatan Kecamatan Getasan, 20016) dan perilaku makan masyarakat getasan hampir seragam dimana jenis makanan yang dikonsumsu dan cara pengolahan bahan makanan yang sama, hal tersebut membuat peneliti memilih getasan sebagai lokasi penelitian. Berdasarkan hal di atas, pada penelitian ini akan menghubungkan antara Diabetes Mellitus dengan Asam Urat dan Hipertensi hal ini dikarenakan kebanyakan masyarakat Kecamatan Getasan menderita hipertensi dan asam uratpeneliti tertarik untuk mengetahui bagaimana hubungan antara diabetes melitus dan asam urat dan pengaruh dari penyuluhan terhadap perubahan pola makan.

\section{METODE}

\section{Sampel Penelitian}

Penelitian dilakukan di Kecamatan Getasan pada bulan April - Juli 2017. Populasi adalah peserta prolanis DM, yang sesuai dengan kriteria yang ditentukan oleh peneliti. Sampel penelitan adalah peserta program pengelolaan penyakit kronis (prolanis) yang berusia 40-80 tahun dan mau dijadikan sebagai sampel tetap.

\section{Teknik Pengumpulan Data}

Pengumpulan data menggunakan teknik Pre-post test dilakukan dengan melaksanakan pemeriksaan biokimia yang meliputi pemeriksaan gula darah, asam urat danekanan darah dengan menggunakan alat tes kadar gula darah dan asam urat dengan merek Nesco GCU meter . Pre test dilaksanakan pada bulan April setelah pemeriksaan biokimia sampel penelitian diberikan penyuluhan tentang pola makan yang baik daan benar untuk penderita DM. post test dilaksanakan pada bulan Juli dengan melakukan pemeriksaan biokimia serta pengisian formulir frekuensi pangan. Analisis Data

Analisis data menggunakan SPSS versi 16 dengan uji paired t-test dan uji kendallsyang dilakukan untuk mengetahui seberapa besar pengaruh dari penyuluhan terhadap perubahan pola makan penderita diabetes mellitus di Kecamatan Getasan, serta hubungan antara diabetes melitus dan asam urat. Data yang digunakan adalah hasil pemeriksaan parameter biokimia pada pre-test dan post-test.

\section{HASIL}

Jumlah sampel penelitian menurut umur dan diagnosis ditunjukan pada Tabel 1. Sampel berasal dari wilayah Puskesmas Getasan (60 sampel) dan Puskesmas Jetak (40 sampel), yakni dari desa/dusun: Wates, Batur, Getasan, Tekelan, Piji, Sumogawe, Tajuk, Banaran, Sidomukti, Ngrawan, Kopeng, Ngablak yang terdapat di Kecamatan Getasan , Kabupaten Semarang. Sebagian besar sampel bermata pencaharian sebagai petani dan wiraswasta.

Tabel 1. Data jumlah sampel berdasarkan usia dan diagnosa

\begin{tabular}{cccccccccc}
\hline & \multicolumn{1}{c}{ Jumlah Penderita } \\
\cline { 2 - 9 } Diagnosa & \multicolumn{2}{c}{$40-50$} & \multicolumn{2}{c}{$51-60$} & \multicolumn{2}{c}{$61-70$} & \multicolumn{2}{c}{$71-80$} \\
\cline { 2 - 9 } & Pria & Wanit & pria & wanita & pria & wanita & Pria & Wanit \\
DM & 1 & 12 & 1 & 10 & 1 & 2 & 1 & 2 \\
DM + asam urat & 3 & 5 & 4 & 6 & 1 & 1 & 0 & 2 \\
DM + hipertensi & 4 & 8 & 1 & 12 & 1 & 1 & 0 & 3 \\
DM+asam & 3 & 3 & 3 & 3 & 1 & 3 & 0 & 2 \\
urat+hipertensi & 3 & & & & & & & &
\end{tabular}

Pada pemeriksaan parameter biokimia awal (pre-test), ditemukan sampel yang menderita DM tanpa komplikasi sebanyak 30 orang, sedangkan sampel yang mengalami komplikasi DM 
dengan asam urat, DM dengan hipertensi, dan DM dengan asam urat dan hipertensi berturut-turut 22, 30, dan 18 orang. Menurut jenis kelamin, jumlah penderita DM dengan dan tanpa komplikasi lebih banyak pada wanita ( 75 orang dari 100 orang sampel), sedangkan menurut umur 40-50 tahun (39 orang) dan 50-60 tahun (40 orang) (Tabel 1).

\section{Profil Kadar Gula Darah}

Hasil pre-test dan post-test kadar gula darah sampel pria dan wanita bervariasi. Kadar gula darah pria mengalami penurunan sebesar $68 \%$ tetapi terdapat $32 \%$ yang mengalami kenaikan. Persentase sampel wanita yang mengalami penurunan kadar gula darah lebih rendah dari pria yakni sebesar 53,30\%, tetapi jumlah sampel yang mengalami peningkatan kadar gula darah lebih tinggi dari pria yakni sebesar 38,70\% (Tabel 2).

\section{Profil Kadar Asam Urat}

Dari pemeriksaan parameter asam urat didapatkan 22 orang yang menderita diabetes mellitus dengan komplikasi asam urat. Kadar asam urat pada sampel pria mengalami penurunan sebesar $84 \%$ dan terdapat peningkatan sebesar $16 \%$. Persentase pada sampel wanita $53,30 \%$ mengalami peningkatan kadar asam urat dan pada peningkatan persentase sampel wanita lebih tinggi yaitu $38,70 \%$. (Tabel 2).

\section{Profil Tekanan Darah}

Hasil dari pemeriksaan tekanan darah pada sampel pria dan wanita didapatkan 50\% dari sampel mengalami penurunan tekanan darah dan $30 \%$ mengalami peningkatan tekanan darah, namun ada pula $20 \%$ sampel yang memiliki tekanan darah yang turun menuju ke angka normal (Tabel 2).

Tabel 2. Frekuensi Sampel yang Mengalami Perubahan Kadar gula, Asam urat, dan Hipertensi

\begin{tabular}{|c|c|c|c|c|c|c|c|c|c|}
\hline \multirow[t]{2}{*}{ Sampel } & \multicolumn{3}{|c|}{$\begin{array}{l}\text { Perubahan kadar gula } \\
\text { darah (orang) }\end{array}$} & \multicolumn{3}{|c|}{$\begin{array}{l}\text { Perubahan kadar } \\
\text { asam urat (orang) }\end{array}$} & \multicolumn{3}{|c|}{$\begin{array}{l}\text { Perubahan tekanan } \\
\text { darah (orang) }\end{array}$} \\
\hline & Naik & $\begin{array}{l}\text { Turu } \\
\mathrm{n}\end{array}$ & $\begin{array}{l}\text { Norma } \\
1\end{array}$ & Naik & $\begin{array}{l}\text { Turu } \\
n\end{array}$ & $\begin{array}{l}\text { Norma } \\
1\end{array}$ & Naik & $\begin{array}{l}\text { Turu } \\
\mathrm{n}\end{array}$ & Normal \\
\hline DM & 16 & 9 & 5 & 10 & 9 & 11 & 6 & 7 & 16 \\
\hline $\begin{array}{l}\text { DM + Asam } \\
\text { urat }\end{array}$ & 5 & 4 & 13 & 10 & 7 & 5 & 3 & 7 & 12 \\
\hline DM + Hipertensi & 17 & 3 & 10 & 11 & 4 & 15 & 12 & 17 & 1 \\
\hline $\begin{array}{l}\text { DM + Asam } \\
\text { urat + } \\
\text { Hipertensi }\end{array}$ & 6 & 4 & 8 & 3 & 3 & 12 & 4 & 8 & 6 \\
\hline
\end{tabular}

Pengujian hipotesis dengan uji statistik korelasi bivariate dimana $\mathrm{H}_{1}=$ ada hubungan antara diabetes mellitus dengan komplikasi penyerta dan $\mathrm{H}_{0}=$ tidak ada hubungan antara diabetes mellitus dengan komplikasi penyerta dengan nilai kemaknaan 0,05. Menunjukan hasil bahwa ada hubungan antara diabetes mellitus dengan asam urat yang dibuktikan dengan hasil uji $\mathrm{P}=0,040$ dimana nilai $\mathrm{P}$ $<0,05$, dan hubungan antara diabetes mellitus dengan hipertensi menunjukan hasil $\mathrm{P}=0,044$ dimana nilai $\mathrm{P}<0,05$ maka $\mathrm{H}_{1}$ diterima bahwa ada hubungan antara diabetes mellitus dengan hipertensi. Pada pengujian ketiganya didapatkan hasil $\mathrm{P}=0,020$ dimana $\mathrm{P}<0,05$ maka $\mathrm{H}_{1}$ diterima bahwa ada hubungan antara diabetes mellitus dengan asam urat dan hipertensi.

\section{Hubungan Penyuluhan dan Perubahan Kadar Gula Darah, Asam Urat, dan Hipertensi}

Dari total sampel penelitian terdapat 66 orang yang mengikuti penyuluhan tentang pola makan yang benar bagi penderita diabetes mellitus. Informasi yang didapatkan dari penyuluhan diterapkan oleh 70 orang dan yang tidak dijalankan 30 orang Kepatuhan terhadap pola makan yang benar memberikan dampak terhadap penurunan kadar gula darah, asam urat, dan tekanan darah pada sampel. Terdapat 20 orang yang menerapkan informasi yang didapatkan dari penyuluhan dan mengalami penurunan kadar gula darah, dan 28 orang mengalami peningkatan kadar gula darah. Peningkatan dan penurunan kadar gula darah dapat dilihat pada Gambar 1. 

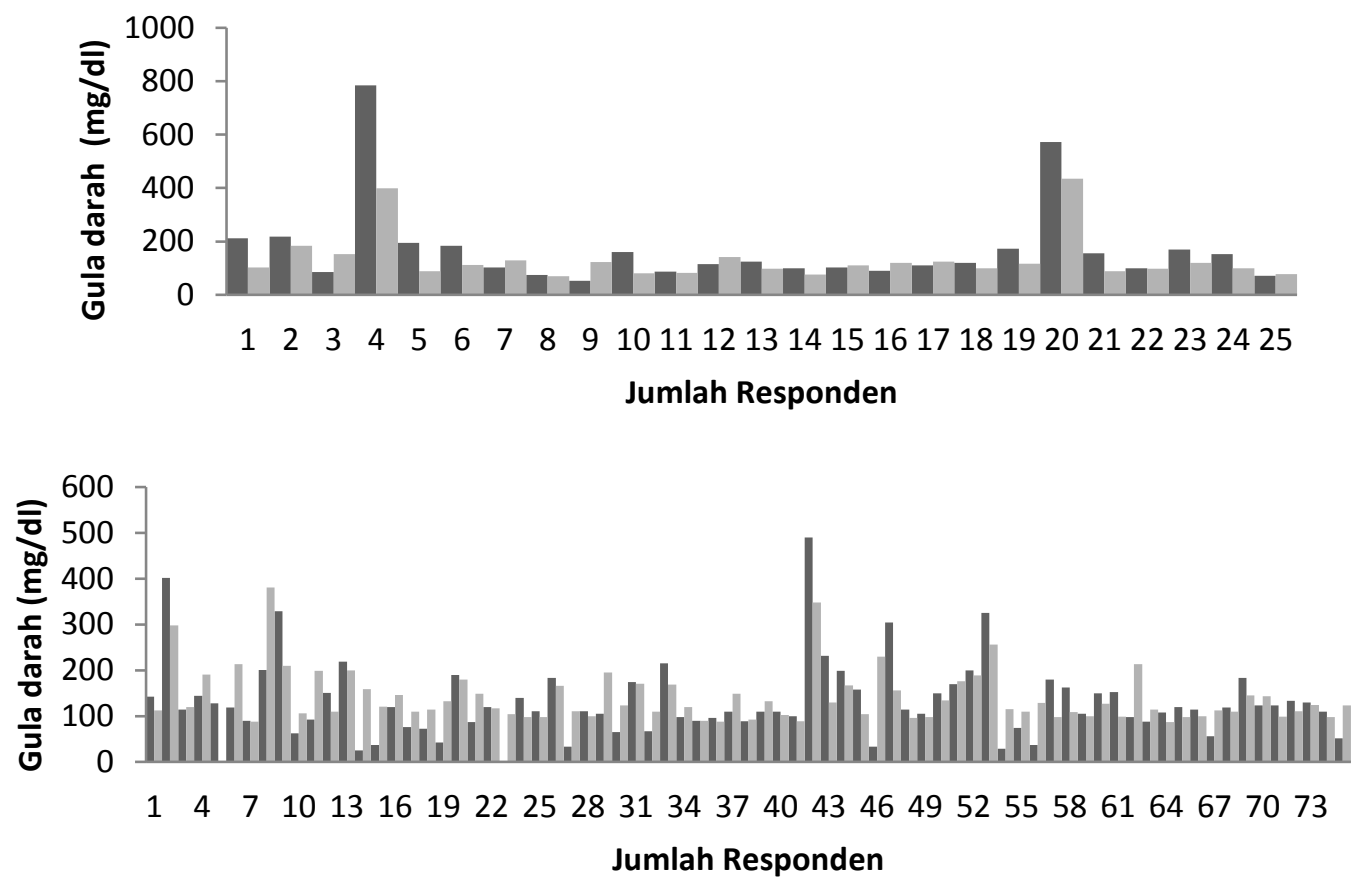

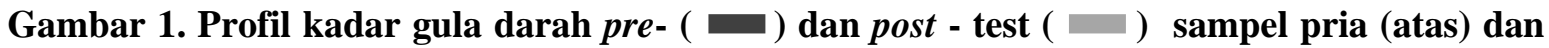 wanita (bawah)}

Hasil formulir frekuensi pangan yang diisi oleh sampel menunjukkan bahwa konsumsi beras atau nasi putih merupakan makanan pokok semua sampel baik sebelum dan setelah diberikan penyuluhan. Jenis protein hewani yang sering dikonsumsi per bulan adalah telur ayam, sedangkan daging ayam ataupun daging sapi yang dikonsumsi sesekali dalam satu bulan. Selanjutnya untuk protein nabati, sampel selalu mengonsumsi tahu dan tempe sebagai lauk utama saat makan, sedangkan untuk sayuran hampir semua jenis sayuran dikonsumsi kecuali beberapa jenis yang memang tidak dianjurkan oleh dokter seperti kangkung, kembang kol, kubis, dan sawi.

\section{Pembahasan}

Hasil pemeriksaan biokimia respoden penelitian ada pada tiga kategori yaitu normal, meningkat dan menurun. Penyebab meningkat atau menurunnya kadar biokimia tidak hanya disebabkan oleh konsumsi obat-obatan namun dapat dikarenakan pola makan sampel itu sendiri. Hal ini dipengaruhi oleh aktivitas dan kebiasaan makan sampel penelitian yang rata-rata bekerja sebagai petani, pedagang dan pegawai negeri sipil (PNS). Pemilihan bahan makanan dan cara pengolahan makanan juga berpengaruh terhadap meningkat atau menurunnya kadar biokimia sampel.

Dari hasil pemeriksaan biokimia yang meliputi pemeriksaan kadar gula darah dan kadar asam urat dapat diketahui bahwa adanya perubahan walaupun tidak semua perubahan menuju normal perubahan paling menonjol ada pada sampel wanita dimana penuruan kadar gula darah dan kadar asam urat cukup cepat dibandingkan pada sampel pria yang msih ada beberapa sampel yang memiliki kadar gula darah atau kadar asam urat yang meningkat dari pre test hal ini di sebabkan oleh banyak faktor diantaranya konsumsi obat, pola makan yang tidak teratur, kebiasaan makan di luar rumah dan aktivitas fisik.

Dari penelitian yag telah dilaksanakan diketahui adanya hubungan yang signifikan antara diabetes mellitus dengan asam urat hal ini disebabkan oleh gangguan pada sirkulasi darah dimana resistensi insulin pada penderita diabetes mellitus adalah faktor utama pemicu timbulnya asam urat selain itu dibuktikan dengan hasil uji kendalls tau menunjukan bahwa nilai $\mathrm{P}=0,04$ dimana $0,04<0,05$ yang artinya signifikan ada hubungan antara diabetes melitus dengan asam urat. Hasil penelitian yang dilakukan serupa dengan hasil penelitian yang dilakukan oleh Pradani (2013) yang megatakan bahwa apabila konsentrasi asam urat meningkat maka akan terjadi peningkatan resistensi insulin yang dapat menyebabkan timbulnya penyakit diabetes melitus. 
Hasil serupa juga didapatkan pada penelitian lain yang dilakukan oleh Meisinger, dkk. (2012) yang menyatakan adanya korelasi positif antara kadar asam urat dan kadar gula darah pada pasien pre-diabetes, pasien baru diabetes, dan pasien diabetes melitus tipe 2 . Lebih lanjut dikatakan kadar asam urat akan meningkat seiring dengan meningkatnya gula darah sampai batas $8 \mathrm{mmol} / \mathrm{L}$ dan akan menurun setelah kadar gula darah melewati $10 \mathrm{mmol} / \mathrm{L}(\mathrm{p}<0,01)$. Hasil ini berkaitan erat dengan akan terjadinya glikosuria pada kadar glukosa diatas $10 \mathrm{mmol} / \mathrm{L}$ yang mengakibatkan hiperfiltrasi ginjal yang berakhir pada penurunan kadar asam urat. Hasil dari penelitian menyebutkan bahwa asam urat memiliki hubungan yang signifikan dengan kadar gula darah $(\mathrm{OR}=1,57)$ dan tidak memiliki hubungan yang signifikan dengan kadar gula darah 2 pp pada pasien toleransi glukosa terganggu. Lebih lanjut, dijelaskan bahwa kadar asam urat akan meningkat pada pasien prediabetes dan pasien yang baru didiagnosis DM tipe 2 .

Selain itu hasil pemeriksaan biokimia respoden penelitian ada pada 3 kategori yaitu normal, meningkat dan menurun. Penyebab meningkat atau menurunnya kadar biokimia tidak hanya disebabkan oleh konsumsi obat-obatan namun dapat dikarenakan pola makan sampel itu sendiri. Hal ini dipengaruhi oleh aktivitas dan kebiasaan makan sampel penelitian yang rata-rata bekerja sebagai petani, pedagang dan pegawai negri sipil (PNS). Pemilihan bahan makanan dan cara pengolahan makanan juga berpengaruh terhadap meningkat atau menurunnya kadaar biokimia sampel.

Penelitian ini juga membahas mengenai hubungan antara diabetes melitus dengan kejadian hipertensi dimana, apabila tekanan darah sampel meningkat maka sensitivitas darah terhadap insulin menjadi sangat rendah. Oleh karena itu, sampel dengan tekanan darah tinggi (hipertensi) di sarankan mengonsumsi makanan rendah lemak dan mengonsumsi makanan berserat agar membantu meningkatkan resistensi insulin. Hal serupa juga pernah diteliti oleh Gibney (2009) dimana hasil mengatakan bahwa hubungan antara hipertensi dan diabetes melitus sangatlah kompleks, hipertensi dapat membuat sel darah tidak sensitif terhadap insulin. Sebaliknya apabila resistensi insulin berlebihan maka akan menimbulkan peningkatan resistensi natrium dalam darah dan menyebabkan hipertensi.

Berdasarkan hasil uji statistik paired t-test, pada hasil hubungan penyuluhan dengan perubahan kadar gula darah dinyatakan tidak signifikan. Hal ini disebabkan oleh sampel masih mengonsumsi obat dibuktikan dengan hasil uji regresi linier dengn hasil $\mathrm{R}$ square $=0,006(<0,005)$ hal ini menunjukan bahwa obat mempengaruhi penurunan gula darah selain itu peningkatan juga dikarenakan pola makan yang salah serta jam makan yang tidak teratur. Hal ini mengacu pada saran $3 \mathrm{~J}$ untuk penderita diabetes melitus, dari hasil penyuluhan didapatkan 55 orang yang mau mengikuti anjuran pola makan yang diberikan dibuktikan dengan formlir frekuensi pangan dan menurunnya kadar gula darah, kadar asam urat dan tekanan darah menuju normal, 30 orang tidak mengikuti anjuran pola makan yang diberikan hal ini dibuktikan dengan formulir frekuensi pangan yang masih sama bahkan ada beberapa makanan yang tidak dianjurkan serta meningkatnya kadar gula darah, kadar asam urat, dan tekanan darah, dan 15 orang hanya mengikuti setengah dari anjuran pola makan yang diberikan.

\section{KESIMPULAN}

Hasil dari penelitian yang dilakukan terdapat hubungan antara diabetes meltus dengan kejadian asam urat dan tidak ada hubungan antara pemberian penyuluhan terhadap perubahan pola makan sampel penelitian.

\section{KEPUSTAKAAN}

Anna, L. K., Asep. C., 2011. Diabetes Sahabatnya Hipertensi.[ internet] diakses[30november2016] http://health.kompas.com/read/2011/06/08/16102254/Diabetes.Sah abatnya.Hipertensi.

Caroline K, Denise V, Simerjot K, Elizabeth B. The serum uric acid levels improve the prediction of the incident type 2 diabetes in individuals with impaired fasting glucose levels. The Rancho Bernardo Study. Diabetes Care.2009;32(7):1272-73.

Depkes. Riset Kesehatan Daerah. Jakarta: Depkes RI; 2013. 
Herman JB, Medalie JH, Goldbourt U. Diabetes, prediabetes and uricaemia.Diabetologia.2011;1976;12(1):47-52.

Hidayat, I.Kadar Asam Urat pada DM Tipe 2 yang Mengalami Stroke Iskemik. [Tesis]. Universitas Sumatera Utara. 2012

Perkeni. Konsensus Pengelolaan dan Pencegahan Diabetes Mellitus Tipe 2 di Indonesia. Jakarta:2006.

Profil Kesehatan Kota Salatiga. Penyakit Tidak Menular. Dinas Kesehatan. Salatiga. 2014

Profil Kesehatan Kecamatan Getasan. Penyakit Tidak Menular. Puskesmas Getasan. 2016

PB PERKENI. Konsensus pengelolaan dan pencegahan diabetes melitus tipe 2 di Indonesia. Jakarta; 2011.

Prabowo, T. Hubungan antara Hiperurikemia dan Stroke yang Berat pada Diabetes Mellitus Tipe 2.[Tesis] Universitas Gadjah Mada.2007.

Sari NK, Pramono A. Status Gizi, Penyakit Kronis, Dan Konsumsi Obat Terhadap Kualitas Hidup Dimensi Kesehatan Fisik Lansia. Journal of Nutrition College. 2014;3:83-9.

Slamet S. Diet pada diabetes Dalam Noer dkk.Buku ajar ilmu penyakit dalam. Edisi III.Jakarta: Balai Penerbit FK-ill;2008.

Soegondo S. Konsensus Pengelolaan dan Pencegahan DM Tipe 2 di Indonesia:Perkeni:1-78. Jakarta. 2011.

Soeroso dan Algristian Asam Urat. Jakarta : Penebar Plus. 2011.

Sri W.N, Burhanuddin B, Abdul S, Gambaran Asupan Purin, Penyakit Artritis Gout, Kualitas Hidup Lanjut Usia Di Kecamatan Tamalanrea. Jakarta . 2012

Mossanda, K. S., Bolajoko, E. B., Moropane, M., et al. Antioxidant and Oxidative Stress Status in Type 2 Diabetes and Diabetic Foot Ulcer. JEMDSA. 13(2): 58-63.2008

Sautin, Y. Y., Richard, J. J. Uric Acid: TheOxidant-Antioxidant Paradox. Nucleosides Nucleotides Nucleic Acids. 27(6): 608-19.2008.

Alderman, M. H. Uric Acid and CardiovascularDisease. Circulation. pp: 880-3.2007.

Brown, C. T.,. Penyakit Aterosklerotik Koroner. In: Sylvia, A. P., Lorraine, M. W. (eds). Patofisiologi: Konsep Klinis Proses-proses PenyakitVolume 1. Cetakan I. Jakarta: EGC. pp: 576-6.2006.

Meisinger C, dkk . Uric Acid is More Strongly Associated with Impaired Glucose Regulation in Woman than in Men from the General Population: The KORA F4-Study. Plos ONE. 7(5).2012.

Siregar Masra, Nurkhalis. Correlation between Serum Blood Glucose with Serum Uric Acid in type 2Diabetes Mellitus. Aceh. 2014 